\title{
Trophic structure and interactions in Lake Ayamé (Côte d'Ivoire)
}

\author{
A. Traore ${ }^{(1)}$, A. Ouattara ${ }^{(1)}$, L. Doumbia ${ }^{(1)}$, L. Tah ${ }^{(2)}$, J. Moreau $^{(3)}$, \\ G. Gourène ${ }^{(1)}$
}

Received February 19, 2008 / Reçu le 19 février 2008

Accepted May 5, 2008 / Accepté le 5 mai 2008

\begin{abstract}
Key-words: The Ecopath software with Ecosim and Ecospace was used to describe trophic dynamic, transfer efficiency, Ecopath, Lake Ayamé, West Africa structure and trophic relationships in Lake Ayamé. The total biomass of fish is $8 \mathrm{t} . \mathrm{km}^{-2}$. The trophic levels assessment revealed that the highest value (3.83) was observed in Hepsetus odoe. The mean trophic level of catch (2.94) indicates that fisheries are targeting mainly the fish groups of high trophic levels. Resources are not exploited properly. Competition between species occurs for Sarotherodon melanotheron and Oreochromis niloticus for the first group and Chrysichthys spp. and Heterotis niloticus for the second group. Transfer efficiency is high from producers.
\end{abstract}

\section{ABSTRACT}

\section{RÉSUMÉ}

\section{Structure et interactions trophiques du lac Ayamé (Côte d'Ivoire)}

Mots-clés : lac Ayamé, retenue, relations trophiques, Ecopath
Un modèle décrivant la structure et les relations trophiques du lac Ayamé a été construit à l'aide du logiciel Ecopath associé avec Ecosim et Ecospace. L'analyse de la dynamique de cet écosystème a été effectuée en termes de biomasse, niveau trophique, niveau moyen des captures et transfert d'énergie. La biomasse totale de poisson s'élève à $8 \mathrm{t} . \mathrm{km}^{-2}$. L'estimation des niveaux trophiques attribue le plus haut niveau trophique à Hepsetus odoe avec une valeur de 3,83. La valeur de 2,94 pour le niveau trophique moyen des captures indique que les espèces cibles des pêches se trouvent au niveau supérieur de la pyramide trophique. Les ressources du lac n'ont pas encore atteint le seuil critique de surexploitation. Les compétitions interspécifiques sont peu marquées, notamment chez Sarotherodon melanotheron et Oreochromis niloticus d'une part, et chez Chrysichthys spp. et Heterotis niloticus d'autre part. Le rendement le plus élevé des transferts est enregistré chez les producteurs primaires.

(1) Université d'Abobo-Adjamé (UAA), Unité de Formation et de Recherche en Sciences et Gestion de l'Environnement, Laboratoire d'Environnement et de Biologie Aquatique (LEBA), 02 BP 801 Abidjan 02, Côte d'Ivoire.

(2) Centre de Recherches Océanologiques, BP V 18 Abidjan, Côte d'Ivoire.

(3) Département des Pêches Tropicales, Laboratoire d'Écologie Fonctionnelle, UMR 5245, I.N.PIE.N.S.A.T.

B.P. 107 F, 31326 Castanet Tolosan, France, jmoreau@ensat.fr 


\section{INTRODUCTION}

Understanding the functioning of a complex ecosystem, and the possible impacts of different ecological changes on the system as a whole, calls for quantification of the trophic relationships between different groups in the system. This is one reason why Polovina (1984) developed Ecopath (modified by Christensen and Pauly, 1992; Walters et al., 1999; Christensen et al., 2005), a steady-state model of trophic interactions in ecosystems. The relative simplicity of this model compared with other multispecies models, such as simulation models by Andersen and Ursin (1977), and Laevastu and Larkin (1981), is apparent in its application to several marine and continental ecosystems (Christensen and Pauly, 1993).

This study describes the situation of a tropical man-made lake, Ayamé, in West Africa. This reservoir has been studied by different researchers since its impoundment in 1959 (Daget and Iltis, 1965; Reizer, 1967) and more recently after several years of fishing (Kouamelan et al., 1999; Diomande et al., 2001; Vanga et al., 2002; Ouattara et al., 2003, 2007; Dietoa et al., 2007).

Lake Ayamé presents a significant ichthyological richness. Fish fauna consists of 36 species (Gourène et al., 1999). There are endemic species with two introduced species: Oreochromis niloticus and Heterotis niloticus (Moreau et al., 1988).

This diversity has favoured the development of intense fishing activity in the lake, which was one of the first water bodies where continental fisheries were developed in Côte d'Ivoire (Gourène et al., 1999). This resource exploitation has induced a decrease in catches of the principal species and modification of the fish community structure. For example, the contribution of Oreochromis niloticus to the catch has decreased from $50 \%$ to $3 \%$, whereas the contribution of Sarotherodon melanotheron has increased simultaneously (Gourène et al., 1999).

With Ecopath, the structure and the trophic functioning of Lake Ayamé are presented.

\section{MATERIAL AND METHODS}

\section{> STUDY SITE}

The artificial Lake Ayamé (longitudes $3^{\circ}$ and $3^{\circ} 5$ west, latitudes $5^{\circ} 30$ and $6^{\circ}$ North) results from hydroelectric barrage construction on a coastal river (Bia) in Côte d'Ivoire (Figure 1). The average surface is $180 \mathrm{~km}^{2}$; the lake is $80 \mathrm{~km}$ long and $27 \mathrm{~km}$ wide (at the maximum water level); the maximal depth is $30 \mathrm{~m}$. Average annual precipitation in the region is about $1800 \mathrm{~mm}$. The water level varies between $84.84 \mathrm{~m}$ and $88.44 \mathrm{~m}$ above sea level. The average surface water temperature is $28.4^{\circ} \mathrm{C}$.

Lake Ayamé fishery is predominantly artisanal. Fishermen operate various gears depending on the season, the investment level, the fishing areas and the species targeted. These gears are gillnets, cast nets, long-lines, seines and various kinds of traps (Reizer, 1967).

\section{$>$ THE ECOPATH MODEL}

The Ecopath model is based on varied studies (Polovina, 1984; Polovina and Ow, 1985; Christensen and Pauly, 1992, 1996; Walters et al., 1997, 1999, 2000; Christensen et al., 2005) and was used to construct a steady-state description of Lake Ayamé. The model, which has been used for quantifications of food webs in different ecosystems and impact of fisheries for management purposes, comprises a set of simultaneous linear equations, one for each group under consideration, and assumes a mass balance where the production of the considered group is equal to the sum of all predation, non-predatory losses and export:

$$
\mathrm{B}_{i}{ }^{\star} \mathrm{P} / \mathrm{B}_{i}{ }^{\star} \mathrm{EE}_{i}=\Sigma \mathrm{B}_{j}{ }^{\star} \mathrm{Q} / \mathrm{B}_{j}{ }^{\star} \mathrm{DC} \mathrm{C}_{i j}+\mathrm{Y}_{i}
$$

$\mathrm{B}_{i}$ is the biomass of group $i$ (in t.km ${ }^{-2}$ fresh weight); $\mathrm{P} / \mathrm{B}_{i}$ is the annual production/biomass ratio of $i$ equal to the total mortality coefficient $(Z)$ in steady-state conditions (Allen, 1971); 


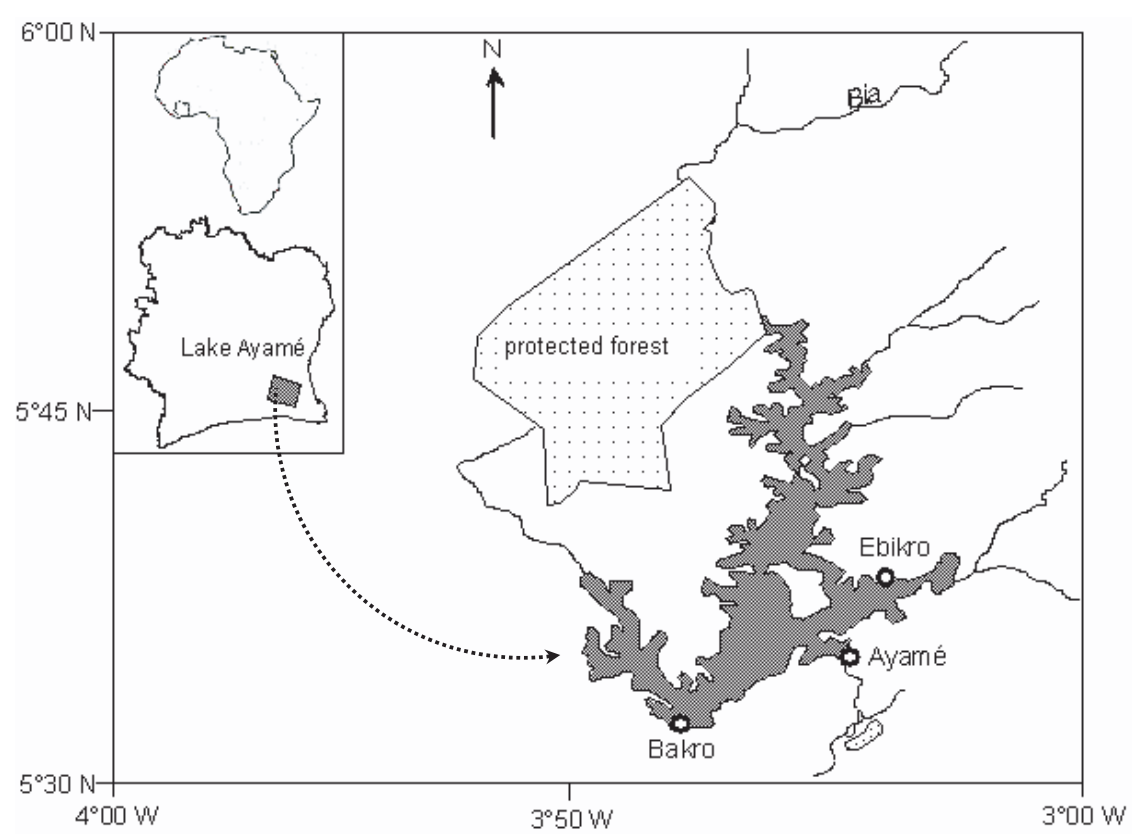

Figure 1

Lake Ayamé, situation map (from Ouattara et al., 2007).

Figure 1

Localisation du lac Ayamé (d'après Ouattara et al., 2007).

$\mathrm{EE}_{i}$ is the ecotrophic efficiency representing the part of the total production consumed by predators or captured in the fishery or exported; $\mathrm{B}_{j}$ is the biomass of the predator group $j$; $\mathrm{Q} / \mathrm{B}_{j}$ is the annual food consumption per unit biomass of the predatory group $j$; $\mathrm{DC}_{i j}$ is the proportion of the group $i$ in the diet of its predator group $j$ and $Y_{i}$ is the export or catch in fishery of group $i$, that is assumed to be exploited in the fishery.

In addition to balancing the model, Ecopath can be used to compute parameters and indices corresponding to the food web characteristics:

The trophic level (TL) is represented as fractions (Odum and Heald, 1975) rather than integers $(1,2,3, \ldots)$ as initially proposed by Lindeman (1942). A routine of Ecopath assigns a definitional trophic level of 1 to producers and detritus and a trophic level of $1+$ [the weighted average of the preys' trophic level] to consumers.

The group-specific omnivory index (OI) is computed as the variance of the TLs of each predator's prey groups (Christensen and Pauly, 1993) while the system omnivory index (SOI) is computed as the average omnivory index of all consumers weighted by the logarithm of each consumer's food intake, $Q$ (Christensen et al., 2000). It indicates the allocation of predator-prey interactions linking each trophic level (Christensen and Walters, 2004). Both OI and SOI indices vary from 0 to 1 .

The connectance index $(\mathbf{C l})$ is the ratio between the number of actual definite trophic associations among all the groups and the theoretical possible number of connections, $(N-1)^{2}$ for $N$ groups, including consumption of detritus (Christensen et al., 2000; Christensen and Walters, 2004). This index is correlated with the maturity, e.g. the level of evolution of the ecosystem, as defined by Odum (1969), because the food chain structure changes from linear to web-like as a system matures (Odum, 1971).

Trophic aggregation per discrete TL, sensu Lindeman (1942), is based on an approach suggested by Ulanowicz (1995). This routine facilitates calculation of flows per TL based on diet compositions by reversing the routine for calculation of fractional trophic levels quoted above. More particularly, the transfer efficiencies between the successive discrete trophic levels are 
calculated as the ratio between the sum of the exports plus the flow that is transferred from one trophic level to the next, and the throughput at this trophic level (Christensen et al., 2000).

The total system throughput (TST) is defined as the sum of all flows in a system (Ulanowicz, 1986) and can be fractionated into import of TL1, export, respiration, consumption by predation and flows going back to detritus (Christensen et al., 2000).

The gross efficiency of the fishery (GEF) is computed as the ratio between the total catch and the total primary production in the system. The value will be higher for systems with a fishery harvesting fish belonging mainly to low TLs than for systems whose fisheries concentrate on high TLs. Therefore, this index may increase with fisheries' 'development' as defined by Pauly et al. (1998).

Primary production required (PPR) and Ecological footprint (EF). The PPR (primary production required) used in Ecopath corresponds to the ecological footprint (EF). For the catch the expression is $\mathrm{EF}=\mathrm{PPR} / \mathrm{PP}{ }^{\star} \mathrm{C}$, where $\mathrm{PP}$ is the total flow out of trophic level I (from primary producers and detritus) and $C$ the catch: this will give the size of the area in square kilometres (assuming the unit is $\mathrm{km}^{-2}$ ) needed to sustain a catch of 1 ton for the given resource.

\section{> MODEL CONSTRUCTION}

The trophic model was constructed using mostly data collected from field surveys from 1995 to 1996 and complemented with information from the literature including FishBase (www.fishbase.org) (Froese and Pauly, 2007). A total of 23 groups (Table I) was considered and the ecological grouping of biological assemblages was made. Fish species were basically categorised and grouped according to their similarities in habitat, maximum body size, feeding habits and physiological behaviour, and ecological distribution in order to keep homogeneous characteristics among the species within each group (Yodzis and Winemiller, 1999; Christensen et al., 2000). For each group, whenever possible, a representative species was selected based on its importance in the fisheries and available information.

\section{> BASIC PARAMETER VALUES}

Data required for the Ecopath model are: biomass $(B)$, ratio production/biomass $(P / B)$, consumption per unit of biomass $(\mathrm{Q} / \mathrm{B})$, catches $(\mathrm{Y})$, diet composition and ecotrophic efficiency (EE).

\section{Basic parameters of fish}

\section{The production/biomass $(P / B)$ ratio}

Whenever possible, the P/B ratio of the fish groups was estimated from recently-collected length-frequency distributions using the FiSAT software (Gayanilo et al., 2002). In a first step, this software was used to estimate the growth parameters of the Von Bertalanffy (1938) Growth Function, i.e., the asymptotic length, $L_{\infty}$, and the growth coefficient, $\mathrm{K}$, which are needed for P/B computation (Gayanilo et al., 2002). Otherwise, the methods of Lévêque et al. (1977), Merona (1983), Pauly (1983) and the predictive models of Froese and Binohlan (2000) were employed to estimate these demographical parameters. Natural mortality, M, was computed using the predictive formula of Pauly (1980). Most of the P/B values were computed by Léonard Tah (personal data).

\section{Relative food consumption $(Q / B)$}

The food consumption per unit of biomass $(\mathrm{Q} / \mathrm{B})$ was estimated using the multiple regression formula of Palomares and Pauly (1998):

$$
\log (Q / B)=5.847+0.280 \log (P / B)-0.152 \log W_{\infty}-1.360 T^{\prime}+0.062 A+0.510 h+0.390 d
$$


Table I

Functional groups considered in Lake Ayamé.

Tableau I

Groupes des espèces considérées dans le lac Ayamé.

\begin{tabular}{|c|c|}
\hline Ecopath group & Species concerned \\
\hline Hepsetus odoe & Hepsetus odoe \\
\hline Hemichromis spp. & $\begin{array}{l}\text { Hemichromis bimaculatus } \\
\text { Hemichromis fasciatus }\end{array}$ \\
\hline Clariidae & $\begin{array}{l}\text { Heterobranchus isopterus } \\
\text { Clarias anguillaris }\end{array}$ \\
\hline Ichtyophagous Mormyrids & Mormyrops anguilloides \\
\hline Insectivorous Mormyrids & $\begin{array}{l}\text { Marcusenius furcidens, Marcusenius ussheri } \\
\text { Mormyrus rume }\end{array}$ \\
\hline Chrysichthys spp. & $\begin{array}{l}\text { Chrysichtys nigrodigitatus } \\
\text { Chrysichtys maurus }\end{array}$ \\
\hline Synodontis/Schilbe spp. & $\begin{array}{l}\text { Synodontis bastiani } \\
\text { Synodontis schall } \\
\text { Schilbe mandibularis }\end{array}$ \\
\hline Heterotis niloticus & Heterotis niloticus \\
\hline Small zoophagous organisms & $\begin{array}{l}\text { Chromidotilapia guntheri } \\
\text { Ctenopoma petherici } \\
\text { Micralestes elongatus } \\
\text { Malapterurus electricus } \\
\text { Petrocephalus bovei }\end{array}$ \\
\hline Barbus spp. & $\begin{array}{l}\text { Barbus trispilos } \\
\text { Barbus ablabes }\end{array}$ \\
\hline Brycinus spp. & $\begin{array}{l}\text { Brycinus imberi } \\
\text { Brycinus derhami, Brycinus nurse } \\
\text { Brycinus macrolepidotus } \\
\text { Brycinus longipinnis }\end{array}$ \\
\hline Labeo parvus & Labeo parvus \\
\hline Sarotherodon melanotheron & Sarotherodon melanotheron \\
\hline Oreochromis niloticus & Oreochromis niloticus \\
\hline Tilapias & $\begin{array}{l}\text { Tilapia busumana } \\
\text { Tilapia zillii } \\
\text { Tilapia hybride }\end{array}$ \\
\hline \multicolumn{2}{|l|}{ Insects } \\
\hline \multicolumn{2}{|l|}{ Annelids } \\
\hline \multicolumn{2}{|l|}{ Molluscs } \\
\hline \multicolumn{2}{|l|}{ Zooplankton } \\
\hline \multicolumn{2}{|l|}{ Phytoplankton } \\
\hline \multicolumn{2}{|l|}{ Macrophytes } \\
\hline \multicolumn{2}{|l|}{ Benthic algae } \\
\hline Detritus & \\
\hline
\end{tabular}


where:

$\mathrm{W}_{\infty}=$ fresh weight;

$\mathrm{T}^{\prime}=1000 /$ Kelvin (Kelvin $=\mathrm{T}^{\circ} \mathrm{C}+273$ );

$A=$ the aspect ratio of the caudal fin, indicative of metabolic activity and expressed as the ratio of the square of the height of the caudal fin and its surface area, $A$, was obtained mainly from FishBase (www.fishbase.org) (Froese and Pauly, 2007).

The parameters $h$ and $d$ concern diet

$$
\begin{aligned}
& h=1, d=0 \text { for herbivorous; } \\
& h=0, d=1 \text { for detritivorous; } \\
& h=0, d=0 \text { for carnivorous. }
\end{aligned}
$$

\section{Biomass (B)}

The biomass $(B)$ of each fish group was estimated assuming equilibrium conditions, such that: $\mathrm{B}=\mathrm{Y} / \mathrm{F}$

where $Y$ is yield in t. $\mathrm{km}^{-2} \cdot \mathrm{yr}^{-1}$ and $\mathrm{F}$ is the coefficient of fishing mortality. $\mathrm{F}$ is the difference between total and natural mortalities: $F=Z-M$, assuming that $Z$ is equal to $P / B$ as indicated by Allen (1971).

\section{Annual fish yield}

The evaluations of actual catches are usually based on landing statistics for each species or group of species included in a box. The total annual catch from the ecosystem concerned was estimated at $1061 \mathrm{t}$ (1995-1996), which was split into two main categories of fishing gears: mesh gillnets and other gears for the multispecies consideration.

\section{Diet composition (DC)}

Diet composition is organised as a matrix. Data have been obtained from FishBase (Froese and Pauly, 2007) and studies from various authors: Kouamelan et al. (1999) for Mormyrus rume, Kouamelan et al. (2000) for Mormyrops anguilloides, Diomande et al. (2001) for Synodontis bastiani, Kone and Teugels (2003) for Sarotherodon melanotheron, and Dietoa et al. (2007) for Brycinus longipinnis. Other fish diet compositions come from VLIR (Vlaamse Interuniversitaire Raad) project unpublished data (Gourène and Ouattara, pers. comm.) (those are: Heterotis niloticus, Marcusenius spp., Synodontis schall, Brycinus spp., Schilbe mandibularis and Clariidae) and FishBase (Froese and Pauly, 2007) (Tilapia spp., Chrysichtys spp., Hepsetus odoe, Hemichromis spp., Ctenopoma petherici, Micralestes elongatus, Malapterurus electricus, Barbus spp., Labeo parvus and Chromidotilapia guntheri).

An average diet composition was calculated whenever several species constitute one group. Import to a system is the consumption of preys that are not a part of the system. Import is treated as a "prey" in the diet composition, and should be entered as a fraction of the total diet.

\section{Ecotrophic efficiency (EE)}

Ecotrophic efficiency was estimated by the software when $B, Q / B$ and $P / B$ were known. Its value is between 0.5 and 0.95 (Ricker, 1969).

\section{Other communitie}

\section{Benthic fauna}

Benthic macrofauna inventory showed 3 groups (oligochetes, molluscs and insects). Insects constitute the richest group in terms of biodiversity (29 taxons). Molluscs are more abundant; about $70 \%$ of the total biomass of the benthic fauna (Diomande and Gourène, 2005). 
The biomasses are: 34.33 t. $\mathrm{km}^{-2}$ for molluscs, $16.85 \mathrm{t} . \mathrm{km}^{-2}$ for insects and $0.44 \mathrm{t} . \mathrm{km}^{-2}$ for annelids (oligochetes).

Annual $P / B$ and $Q / B$ values of 3 and $30 \mathrm{yr}^{-1}$ were used for molluscs, 5 and $25 \mathrm{yr}^{-1}$ for insects, and 10 and $65 \mathrm{yr}^{-1}$ for annelids (Palomares, 1991).

Benthic macrofauna diet compositions were adopted from Lauzanne (1983).

\section{Zooplankton}

The zooplanktonic community includes copepods, cladocerans and rotifers. The average $\mathrm{B}$ is $12.8 \mathrm{t} . \mathrm{km}^{-2}$ (VLIR project unpublished data). Annual $\mathrm{P} / \mathrm{B}$ and $\mathrm{Q} / \mathrm{B}$ values, respectively, of $35 \mathrm{yr}^{-1}$ and 140 were adopted from Moreau and Villanueva (2002). Zooplankton diet compositions were adopted from Lauzanne (1983).

\section{Phytoplankton}

The dominant groups are Chlorophytes (Ouattara et al., 2003). Chlorophyll-a concentration showed clear seasonal variations. The Chlorophyll-a content was on average $13 \mathrm{mg} \cdot \mathrm{m}^{-3}$ or $3.9 \mathrm{mg} \cdot \mathrm{m}^{-2}$ when it was extrapolated over $3 \mathrm{~m}$ (i.e. the euphotic zone). Chlorophyll-a concentration was converted into phytoplankton fresh weight following the conversion factor indicated by Ivan et al. (2007): $1 \mathrm{mg}$ chlorophyll-a = $300 \mathrm{mg}$ fresh weight. The resulting fresh biomass is $11.7 \mathrm{t} . \mathrm{km}^{-2}$. The daily primary production was measured at $0.65 \mathrm{~g} . \mathrm{C} . \mathrm{m}^{-2}$ by Ouattara et al. (2007). The annual primary production was computed as 237.2 t.C. $\mathrm{km}^{-2}$. Assuming one g.C is $10 \mathrm{~g}$ fresh weight (Christensen and Pauly, 1993), a value of $2372 \mathrm{t.km}{ }^{-2}$ was obtained. A P/B ratio of $203 \mathrm{yr}^{-1}$ was used as an input in the model.

\section{Benthic algae}

Only limited information was available for this group. Benthic primary production estimations indicated by Dufour (1994) were adopted. Benthic algae production was calculated as $10 \%$ of phytoplankton production. The benthic algae biomass obtained was $1.17 \mathrm{t} . \mathrm{km}^{-2}$. A P/B ratio of $203 \mathrm{yr}^{-1}$ was used as an input in the model.

\section{Macrophytes}

Macrophyte communities were dominated by Pistia stratiotes, Salvinia molesta and Cyperacea.

An input value of 0.950 for EE was used to estimate the biomass based on intense predation noted from Macrophyte consumers. A P/B ratio of $5 \mathrm{yr}^{-1}$ was adopted from Dufour (1994).

\section{Detritus}

A standing stock of $1 \mathrm{t} . \mathrm{km}^{-2}$ (fresh weight) was calculated using the empirical equation of Pauly et al. (1993) based on an annual primary production estimated in the Lake and a euphotic zone of $3 \mathrm{~m}$. It is a required input when using Ecopath.

\section{Balancing the model}

The first step in verifying whether the model output was realistic was to check that the ecotrophic efficiency (EE) was $<1.0$ for all compartments, as values $>1.0$ are inconsistent (that is impossible, under conditions of steady state). The second step in verifying whether the model output was realistic was to check if the production/consumption ratio or gross efficiency (GE) was often between 0.1 and 0.3 (Christensen and Pauly, 1992). Diet composition of some groups was also modified, considering that these were of the highest uncertainty compared with other input variables, to achieve an EE less than 1. 


\section{RESULTS}

The basic input for each of the 23 categorised ecological groups and the parameters computed with the software are presented in Table II, while the relative diet compositions are given in Table III.

\section{> RESOURCES EXPLOITED FOR HUMAN CONSUMPTION}

The total estimated fish biomass is $8.02 \mathrm{t} . \mathrm{km}^{-2}$. Sarotherodon melanotheron $\left(2.51 \mathrm{t} . \mathrm{km}^{-2}\right)$,

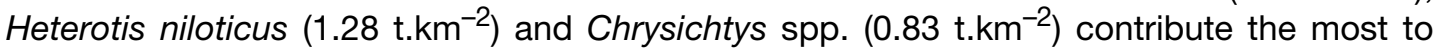
biomass. On the other hand, Clariidae $\left(0.022\right.$ t. km $\left.{ }^{-2}\right)$ and Hemichromis spp. $\left(0.099 \mathrm{t}_{\mathrm{km}} \mathrm{k}^{-2}\right)$ contribute the least. Small species' biomasses, e.g., small zoophagous organisms

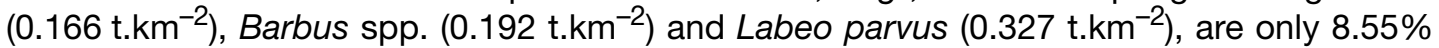
of fish total biomass. EE values calculated for fish are between 0.745 and 0.967 . Most values are high (EE > 0.85).

\section{$>$ TOP PREDATORS}

The highest trophic levels (TLs) were estimated for Hepsetus odoe, Hemichromis spp., ichtyophagous Mormyrids, insectivorous Mormyrids, small zoophagous organisms, Barbus spp., Clariidae and Chrysichtys spp. (TL > 3.0) (Table II) due to their carnivorous feeding ecology (Table III). Most groups belong to TL3 and most are predatory carnivorous.

\section{$>$ INTERMEDIATE PREDATORS}

Intermediate TLs $(2<\mathrm{TL}>3)$ were estimated for Sarotherodon melanotheron, Heterotis niloticus, Synodontis/Schilbe spp., Brycinus spp., Tilapias, Labeo parvus and Oreochromis niloticus.

\section{> LOWEST TL UTILISATION}

EE values for primary producers (phytoplankton, Macrophytes and benthic algae) are high (more than 0.80 ) for several groups which are targeted by predators. They are quite low (less than 0.60$)$ for primary consumers. Molluscs and insects are highly consumed by fish. Zooplankton was not fully utilised due to the benthic fauna abundance.

The $P / Q$ ratios (Table II) are low for Hepsetus odoe, Oreochromis niloticus, Tilapias, Sarotherodon melanotheron and Labeo parvus. The maximum value was obtained for small zoophagous organisms. The value for Hepsetus odoe is low for a top predator; this is in relation to its size and prey size.

\section{> STRUCTURE PER TROPHIC LEVEL}

Most of the fish biomass, catch and ecological production take place at TL3 (Table II and Figure 2). Fishers target mainly the highest TL fish (about 3 or more) as summarised in Table IV.

Moreover, Ecopath usually calculates trophic levels higher than 4 (Ulanowicz, 1995). In the present study, 7 TLs are counted (Table IV), which is due to cannibalism in the highest trophic levels.

Trophic aggregation revealed that transfer efficiency from TL1 (phytoplankton, macrophytes, benthic algae and detritus) to higher TLs is relatively high (about 11\%), as shown in Table V.

The total flow originating from the first trophic level comes from primary producers $(63 \%)$ and only $33 \%$ originates from detritus.

Detritus mainly constitutes primary producers' waste, as the most significant part $(75 \%)$ originates from the primary producers and only $25 \%$ is directed into the system (Table VI). 


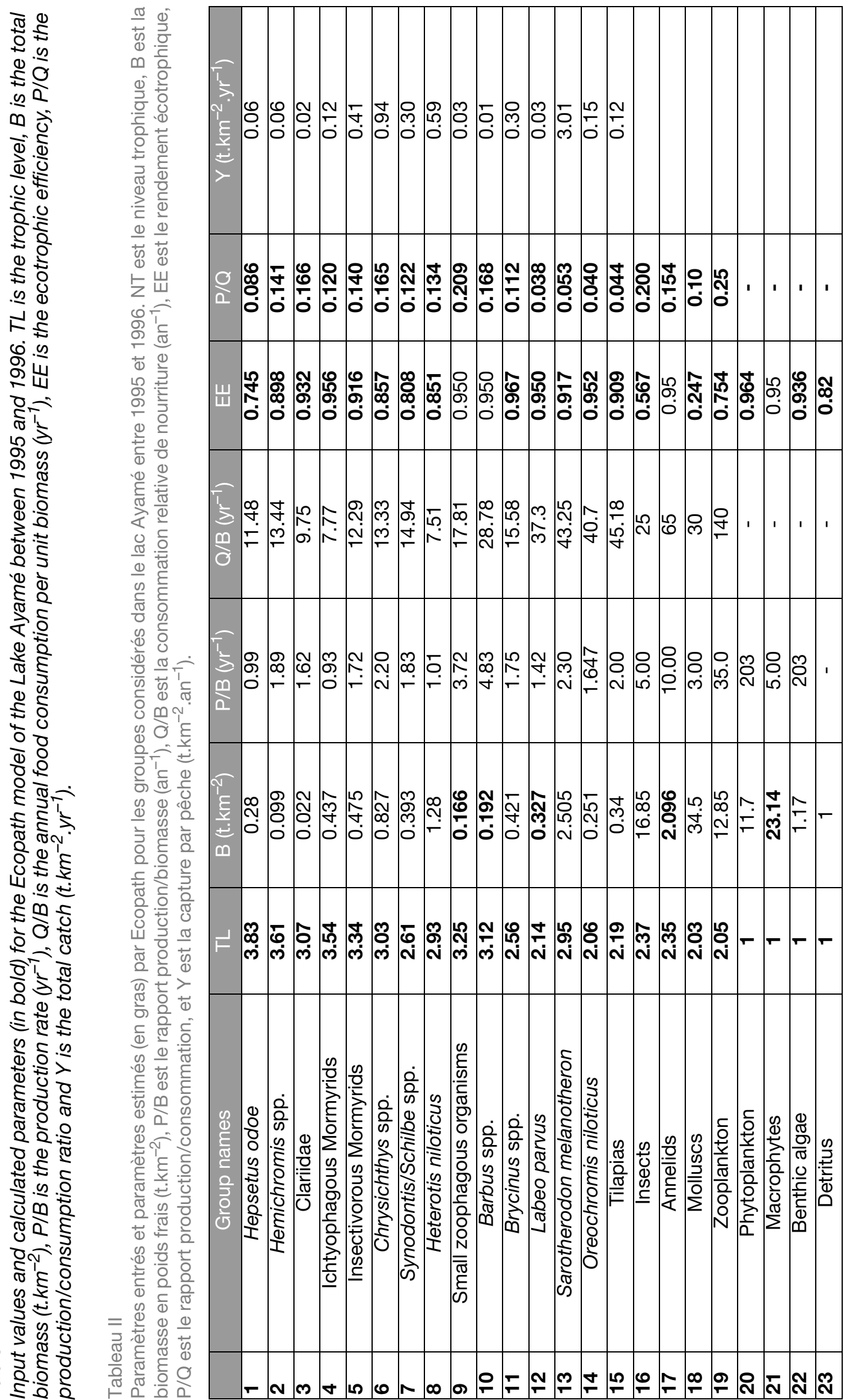




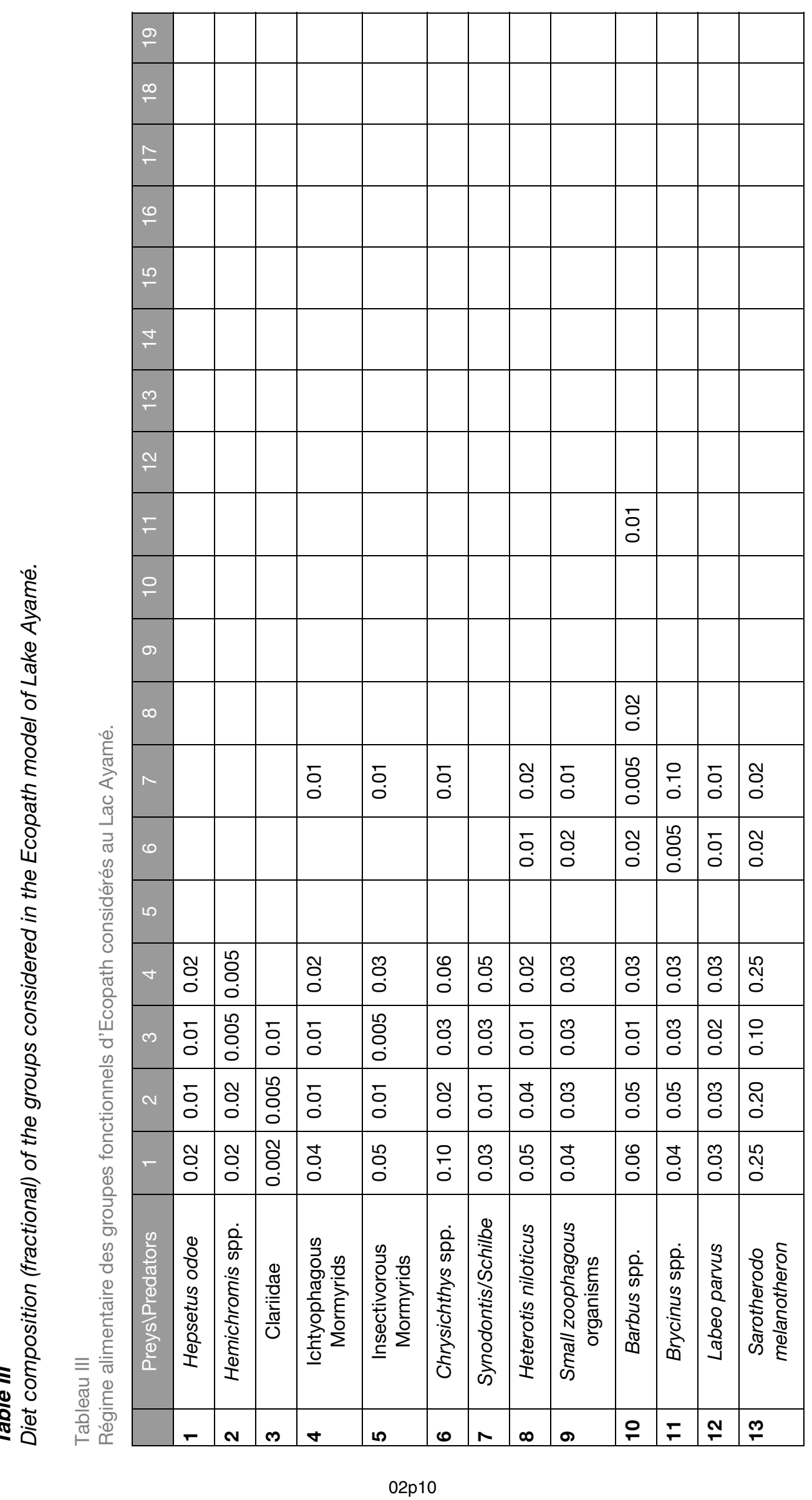




\begin{tabular}{|c|c|c|c|c|c|c|c|c|c|c|c|c|}
\hline 미 & & & & & & $\begin{array}{l}0 \\
0 \\
0\end{array}$ & 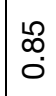 & & & 웅 & & 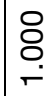 \\
\hline$\stackrel{\infty}{\sim}$ & & & & & & ஜூ & $\frac{1}{\sigma}$ & $\begin{array}{l}\infty \\
0 \\
0\end{array}$ & $\frac{\pi}{\sigma}$ & $\begin{array}{l}8 \\
0 \\
0\end{array}$ & & 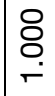 \\
\hline$\stackrel{F}{\digamma}$ & & & ○ִ & L & & 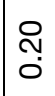 & $\frac{10}{0}$ & & $\frac{10}{0}$ & 吕 & & 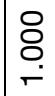 \\
\hline$\stackrel{\oplus}{\sim}$ & & & : & ণo & $\begin{array}{l}2 \\
0 \\
0\end{array}$ & $\begin{array}{l}\stackrel{P}{0} \\
0\end{array}$ & O & 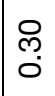 & & 守 & $\stackrel{2}{\circ}$ & 只 \\
\hline$\stackrel{\llcorner}{\leftarrow}$ & & & $\stackrel{2}{2}$ & $\stackrel{2}{2}$ & & $\begin{array}{l}0 \\
0 \\
0\end{array}$ & $\begin{array}{l}0 \\
0 \\
0\end{array}$ & 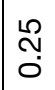 & 음 & ণָ & & $\underset{r}{8}$ \\
\hline$\underset{\ulcorner}{ }$ & & & ¿o & ¿o & & $\begin{array}{l}0 \\
0 \\
0\end{array}$ & $\begin{array}{l}R \\
0 \\
0\end{array}$ & & $\frac{1}{\circ}$ & 우 & & Oִ \\
\hline$\stackrel{m}{\sim}$ & & & & & & প্. & 음 & & & & & \& \\
\hline$\stackrel{\sim}{\simeq}$ & & & \& & O̊ & & ஜ̊ & Nָ & $\begin{array}{l}\delta \\
0\end{array}$ & $\begin{array}{l}2 \\
0\end{array}$ & $\begin{array}{l}\mathscr{0} \\
0 \\
0\end{array}$ & & \& \\
\hline$\mp$ & & & مि & O̊ & & $\widetilde{O}$ & O̊ & $\begin{array}{l}0 \\
10 \\
0\end{array}$ & & 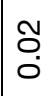 & & 号 \\
\hline 우 & & & م્ & O̊. & & $\begin{array}{l}0 \\
\text { O }\end{array}$ & Õ & & & & & $\underset{-}{8}$ \\
\hline () & & & ? & O & 足 & શ̦ & & & $\overline{0}$ & $\underset{O}{0}$ & & 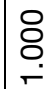 \\
\hline$\infty$ & & & o & $\frac{0}{0}$ & $\begin{array}{l}\infty \\
\check{0} \\
0\end{array}$ & $\frac{N}{0}$ & ڤ̊ & $\frac{10}{0}$ & & 电 & ס्. & 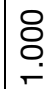 \\
\hline$\Lambda$ & & ర్ & $\frac{1}{0}$ & $\check{\circ}$ & $\begin{array}{l}m \\
0 \\
0\end{array}$ & $\begin{array}{l}\mathscr{0} \\
0 \\
0\end{array}$ & & $\begin{array}{l}\stackrel{\rho}{\infty} \\
0 \\
0\end{array}$ & ஜ̊ & N̦ & $\begin{array}{l}0 \\
0 \\
0\end{array}$ & 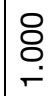 \\
\hline$\bullet$ & ஜ̊ & ర్ & 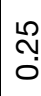 & $\frac{0}{0}$ & ָָ & 으 & $\begin{array}{l}2 \\
0 \\
0\end{array}$ & & $\begin{array}{l}\text { Oे } \\
0\end{array}$ & 우 & 号 & 东 \\
\hline ما & & & L & & & $\begin{array}{l}\text { Oे } \\
\text {. }\end{array}$ & $\begin{array}{l}\sigma \\
0 \\
0\end{array}$ & & & & & 足 \\
\hline$\forall$ & ஜ̊ & $\begin{array}{l}8 \\
0\end{array}$ & 웅 & O & $\begin{array}{l}\widetilde{\sigma} \\
\text { Oे } \\
\end{array}$ & ஜ̊ & ¿o & 号 & $\begin{array}{l}10 \\
0 \\
0\end{array}$ & ơ & $\stackrel{2}{\circ}$ & 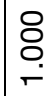 \\
\hline ๓ & ర్ & Oִ & ণ্ণি & Oִ & $\begin{array}{l}1 \\
0 \\
0 \\
0\end{array}$ & $\begin{array}{l}0 \\
0 \\
0\end{array}$ & O̊. & $\begin{array}{l}\infty \\
\vdots \\
0\end{array}$ & Oִ & 足 & مِ & 8 \\
\hline$\sim$ & $\begin{array}{l}10 \\
0 \\
0 \\
0\end{array}$ & 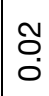 & ֶָ. & 웅 & O̊ & 음 & & & & & 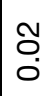 & 号 \\
\hline$\tau$ & ס̊ & O̊ & ¿ & : & ర్ & $\begin{array}{l}0 \\
0 \\
0\end{array}$ & & & & $\begin{array}{l}20 \\
0 \\
0 \\
0\end{array}$ & 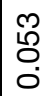 & 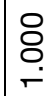 \\
\hline $\begin{array}{l}\frac{0}{0} \\
\frac{0}{10} \\
\frac{0}{0} \\
\frac{0}{\frac{0}{n}} \\
\frac{0}{0} \\
\frac{0}{20}\end{array}$ & 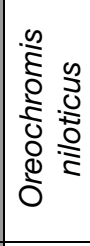 & $\begin{array}{l}\frac{0}{0} \\
\frac{\pi}{2} \\
\frac{\pi}{=} \\
1=\end{array}$ & 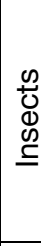 & \begin{tabular}{|l}
$\frac{0}{8}$ \\
$\frac{.0}{0}$ \\
$\frac{5}{4}$
\end{tabular} & 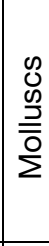 & 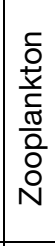 & 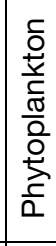 & 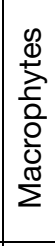 & 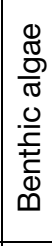 & 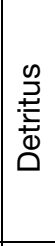 & \begin{tabular}{l}
0 \\
\multirow{t}{0}{} \\
o \\
$\underline{\xi}$
\end{tabular} & $\begin{array}{l}\xi \\
\tilde{\omega}\end{array}$ \\
\hline & $\underset{t}{+}$ & $\stackrel{2}{2}$ & $\stackrel{0}{\circ}$ & $\neq$ & $\stackrel{\infty}{\sim}$ & $\stackrel{9}{\longrightarrow}$ & ฉి & $\bar{N}$ & ส & న & ホ̀ & เి \\
\hline
\end{tabular}



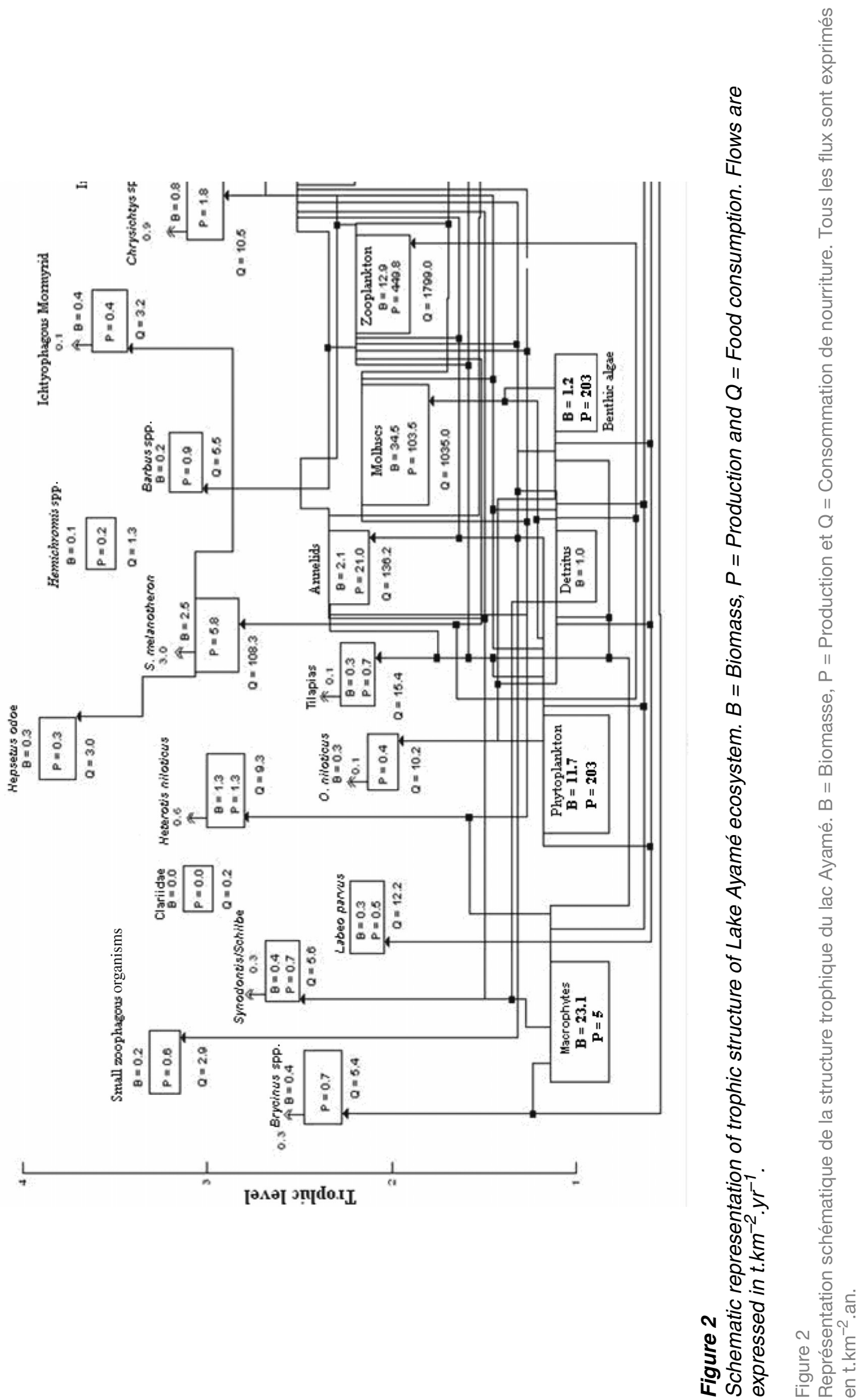
Table IV

Distribution of exploited production, fish biomass and ecological production between trophic levels in Lake Ayamé.

\section{Tableau IV}

Distribution entre différents niveaux trophiques de la production exploitée, de la biomasse et de la production écologique des poissons au lac Ayamé.

\begin{tabular}{|l|c|c|c|}
\hline $\begin{array}{l}\text { TL } \\
\text { (entire number })\end{array}$ & $\begin{array}{c}\text { Catch } \\
\left(\mathrm{t} . \mathrm{km}^{-2} \cdot \mathrm{yr}^{-1}\right)\end{array}$ & $\begin{array}{c}\text { Biomass } \\
\left(\mathrm{t.km} \mathrm{km}^{-2}\right)\end{array}$ & $\begin{array}{c}\text { Ecological production } \\
\left(\mathrm{t.km} \mathrm{km}^{-2} \cdot \mathrm{yr}^{-1}\right)\end{array}$ \\
\hline VII & 0.001 & 0.001 & 0.001 \\
\hline VI & 0.008 & 0.015 & 0.021 \\
\hline V & 0.078 & 0.147 & 0.216 \\
\hline IV & 0.671 & 1.106 & 1.802 \\
\hline III & 4.087 & 4.622 & 9.480 \\
\hline II & 1.289 & 2.124 & 3.636 \\
\hline
\end{tabular}

\section{Table $V$}

Transfer efficiency (\%) at different trophic levels.

Tableau V

Variations des rendements des transferts (\%) selon le niveau trophique.

\begin{tabular}{|l|c|c|c|c|c|c|c|c|}
\hline & \multicolumn{7}{|c|}{ TL } & \\
\hline Sources & I & II & III & IV & V & VI & VII & Average \\
\hline Producers & 15.1 & 11.1 & 11.4 & 11.3 & 11.1 & 10.9 & 10.9 & 12.4 \\
\hline Detritus & 7.3 & 11.5 & 11.5 & 11.2 & 10.9 & 10.9 & & 9.9 \\
\hline Combined & 12.6 & 11.2 & 11.4 & 11.3 & 11.1 & 10.9 & 10.7 & 11.7 \\
\hline
\end{tabular}

Total flow proportion from detritus: 0.33 .

The system omnivory index for Lake Ayamé is relatively high, 0.193 . The omnivory index (OI) of each group in general is high with most of the values greater than 0.2 (Table VI). It means the diet of several organisms is diversified and that these organisms can adapt to environmental changes.

The TL of the fishery is 2.94, which is high. Predators are the most targeted groups. The gross efficiency of fishery (GEF) is quite low (0.002755), as shown in Table VII. This index increases with fisheries' development.

The primary production required (PPR) in order to support the fishery (Pauly and Christensen, 1995) is high, about $36.65 \%$ of the total primary production (Table VII); but a low ecological footprint, about $0.042 \mathrm{~km}^{2}$, is observed.

The connectance index $(\mathrm{Cl})$ is higher $(0.386)$ than the theoretical value $(0.317)$, as presented in Table VII.

\section{DISCUSSION}

The total estimated fish biomass is acceptable $\left(8.02{\left.\mathrm{t} . \mathrm{km}^{-2}\right)}\right.$ when compared with other African inland waters. Indeed, these ecosystem biomasses are estimated at about $10 \mathrm{t} . \mathrm{km}^{-2}$ 
Table VI

Transfer and flow (consumption) proportions from detritus to functional groups of Ecopath, flow transfer of groups to detritus and omnivory index of these groups.

\section{Tableau VI}

Transfert et proportions des flux (consommation) provenant du détritus vers les groupes fonctionnels d'Ecopath, transfert des flux des groupes vers le détritus et indice d'omnivorie de ces groupes.

\begin{tabular}{|c|c|c|c|c|}
\hline Group names & $\begin{array}{l}\text { Group detritus } \\
\text { consumption } \\
\left(\text { t. } \mathrm{km}^{-2}\right)\end{array}$ & $\begin{array}{c}\text { Detritus } \\
\text { consumption } \\
\text { proportion (\%) }\end{array}$ & $\begin{array}{l}\text { Flow to } \\
\text { detritus } \\
\left(\mathrm{t} . \mathrm{km}^{-2}\right)\end{array}$ & $\begin{array}{c}\text { Omnivory } \\
\text { index }\end{array}$ \\
\hline Hepsetus odoe & 0.016 & 0.002 & 0.713 & 0.226 \\
\hline Hemichromis spp. & 0 & 0 & 0.285 & 0.184 \\
\hline Clariidae & 0.011 & 0.001 & 0.045 & 0.637 \\
\hline Ichtyophagous Mormyrids & 0.068 & 0.007 & 0.697 & 0.443 \\
\hline Insectivorous Mormyrids & 0 & 0 & 1.236 & 0.022 \\
\hline Chrysichthys spp. & 1.102 & 0.111 & 2.464 & 0.330 \\
\hline Synodontis/Schilbe spp. & 1.292 & 0.130 & 1.313 & 0.553 \\
\hline Heterotis niloticus & 0.481 & 0.048 & 2.115 & 0.327 \\
\hline Small zoophagous organisms & 0.059 & 0.006 & 0.62 & 0.067 \\
\hline Barbus spp. & 0 & 0 & 1.154 & 0.045 \\
\hline Brycinus spp. & 0.131 & 0.013 & 1.336 & 0.462 \\
\hline Labeo parvus & 7.673 & 0.773 & 2.459 & 0.162 \\
\hline Sarotherodon melanotheron & 0 & 0 & 27.563 & 0.100 \\
\hline Oreochromis niloticus & 1.022 & 0.103 & 2.574 & 0.067 \\
\hline Tilapias & 3.072 & 0.31 & 3.902 & 0.204 \\
\hline Insects & 122.16 & 12.31 & 141.814 & 0.275 \\
\hline Annelids & 54.493 & 5.491 & 35.106 & 0.286 \\
\hline Molluscs & 621 & 62.57 & 336.668 & 0.032 \\
\hline Zooplankton & 179.9 & 18.13 & 560.201 & 0.053 \\
\hline Phytoplankton & & - & 65.085 & - \\
\hline Macrophytes & & - & 11.57 & - \\
\hline Benthic algae & - & - & 11.632 & - \\
\hline Detritus & - & - & - & - \\
\hline
\end{tabular}

(Christensen and Pauly, 1993; Mavuti et al., 1996; Thapanand et al., 2007). This acceptable biomass is due to favourable conditions for fish productivity. Lowe-McConnell (1987) indicated that lakes have more habitats and abundant feed such as plankton and benthos. The fish biomass in Lake Ayamé is low compared with those of lake Nokoué: $132 \mathrm{t} . \mathrm{km}^{-2}$, lagoon Ebrié: 9.5 t.km $\mathrm{km}^{-2}$ and Bagré reservoir: 22.4 t. $\mathrm{km}^{-2}$ (Villanueva et al., 2005; 2006), but it is higher than the biomass recorded for Ubolratana reservoir $\left(6.56{\mathrm{t} . \mathrm{km}^{-2}}^{-2}\right.$ by Villanueva et al. (2005) and Sri Lanka reservoirs $\left(5.0{\left.\mathrm{t} . \mathrm{km}^{-2}\right)}^{2}\right.$ by Haputhantri et al. (2008). The fish biomass in 
Table VII

Summary statistics and flow network indices of Lake Ayamé.

Tableau VII

Statistiques globales et indices des réseaux de flux du lac Ayamé.

\begin{tabular}{|c|c|}
\hline Parameters and index & Values \\
\hline Sum all consumptions (t.km $\left.{ }^{-2} \cdot \mathrm{yr}^{-1}\right)$ & 3593.126 \\
\hline Sum of flow to detritus (t.km ${ }^{-2} \cdot \mathrm{yr}^{-1}$ ) & 1210.553 \\
\hline Mean trophic level of catch & 2.94 \\
\hline Gross efficiency fishery (catch/PPnet) & 0.002755 \\
\hline Calculated total net primary production (t.km $\left.{ }^{-2} \cdot \mathrm{yr}^{-1}\right)$ & 2226.248 \\
\hline Primary production required for catch $\left(\mathrm{t} . \mathrm{km}^{-2} \cdot \mathrm{yr}^{-1}\right)$ & 816.05 \\
\hline Total biomass (excluding detritus) & 110.32 \\
\hline Total catches (t.km+2. $\left.\mathrm{yr}^{-1}\right)$ & 6.133 \\
\hline Connectance index (IC) & 0.386 \\
\hline System omnivory index (SOI) & 0.193 \\
\hline Ecologic footprint $\left(\mathrm{km}^{2}\right)$ & 0.042 \\
\hline Ascendancy (\%) & 26.40 \\
\hline Overhead (\%) & 73.60 \\
\hline
\end{tabular}

the fresh water of Lake Ayamé is similar to what was computed by Christensen (1998) in marine water: $7.1 \mathrm{t} . \mathrm{km}^{-2}$.

Ecotrophic efficiencies of fish groups are variable (but most are $>0.8$ ). Groups for which EE is low suggest a limited exploitation, as these fishes have no significant predators in the lake and are poorly targeted by fishermen. On the other hand, the groups which display high EE values, e.g., Oreochromis niloticus, ichtyophagous Mormyrid and Brycinus spp., are intensively exploited and suffer a high level of predation. Such high EE values of most groups (particularly fish EE values) were noted in other studies, e.g. in Bagré reservoir (Villanueva et al., 2005). Primary producers have a high EE value, indicating that these groups are the base food source in Lake Ayamé. They are fully utilised by organisms at higher trophic levels. This may be attributed to the abundance of fish consuming this group. The higher EE of primary producers means that the Lake Ayamé ecosystem has a bottom-up control. The important contribution of detritus in the food base was observed in Lake Nokoué (Villanueva et al., 2006). This is not the case in Bagré reservoir (Villanueva et al., 2005). A high value of EE is also noted for zooplankton but is exploited by most zoophagous organisms (insects, small zoophagous organisms) and fish juveniles. Moreover, this resource also seems to be exploited by Sarotherodon melanotheron, usually regarded as herbivorous, which becomes zooplanktonophagous in Lake Ayamé. This possible adaptation of Sarotherodon melanotheron can be explained by feed flexibility (Pauly et al., 1988; Paugy, 1994; Blaber, 2000; Kone and Teugels, 2003).

Ichtyophagous fish (Hepsetus odoe) have quite a low $P / Q$ value. This unusual situation might come from the relatively small size of this fish, which cannot attack large fishes as prey. Somehow, when their small preys become less available due to predation and catch pressure, their ichtyophagous character could be modified. However, a high $P / Q$ ratio is estimated for zoophagous organisms due to their carnivorous feeding habits, and this is in relation to their small size. This case was also observed in Lake Kivu for zoophagous Haplochromis (Villanueva et al., 2007). Benthophagous groups also have a high P/Q. 
This situation is in relation to the abundant biomass of benthic organisms observed in Lake Ayamé. This significant biomass has been noted in various lakes such as Lake George (Moreau et al., 1993), Lake Ihema (Mavuti et al., 1996) and Lake Victoria (Villanueva and Moreau, 2001). The low $P / Q$ ratios obtained for Oreochromis niloticus and Tilapias are in agreement with the low quality of their preferred preys, which are principally phytoplankton and decaying organic material.

The Lake Ayamé trophic chain is relatively longer, as indicated by the highest trophic level, which is $>3$. Generally trophic level does not exceed 4 (Ulanowicz, 1995). Similar results are observed in other aquatic systems such as Lake Tchad (Palomares, 1991) and lagoon Ebrié (Villanueva et al., 2006). This trophic chain is based on primary producers and organisms of trophic level II which constitutes zooplankton, molluscs, annelids, insects, Oreochromis niloticus, Labeo parvus, Tilapias and Brycinus spp. The trophic level II favours most flow transfers to the highest trophic level. Indeed, primary producers' abundance governs that of primary consumers, which constitutes the highest trophic level prey and supports fisheries (Pauly and Christensen, 1995). This situation could justify the importance of catch, biomass and ecologic production of Sarotherodon melanotheron, Heterotis niloticus and Chrysichthys spp. at trophic level III. These species are important for the functioning of the lake in terms of fish production. The regulation of this lake is clearly a "bottom-up" control; this concords with ecological theory, which states that bottom-up forces would dominate the ecosystem process (Platts and Ulanowicz, 1985; Dyer and Letourneau, 2003).

The average transfer efficiency is relatively high (11\%). This is most probably due to the utilisation of the ecological production of the fish groups by fisheries and predation as revealed by the high EEs of several groups. This average transfer efficiency noted in Lake Ayamé is high when compared with those observed in lake Nakuru $(<8 \%)$ by Moreau et al. (2001), in Ria Formosa reservoir $(<6.0 \%)$ by Gamito and Erzini $(2005)$ and in Pasak Jolasid reservoir (5.3\%) by Thapanand et al. (2007). Other studies (e.g. by Villanueva et al., 2005, in Bagré reservoir: $>13 \%$ ) showed the highest values when compared with the Lake Ayamé value. The high transfer efficiency in Lake Ayamé may be attributed to the high diversity of predators in this ecosystem. The significance of biodiversity in assuring ecosystem stability has been evoked by Naeem and Li (1997), and Loreau et al. (2001). Moreover, Christensen (1995) suggests that system ascendancy and overhead can be considered as possible measurements of ecosystem stability. The values obtained for our model $(26 \%$ for ascendancy, $74 \%$ for overhead) indicate a good stability of the ecosystem of Lake Ayamé. This stability is due to the greater biodiversity of Lake Ayamé. Most authors (e.g. Castillo et al., 2000; Perez-España and Arreguin-Sanchez, 1999; 2001) have promoted this idea.

The importance of relative total flow from detritus in Lake Ayamé can be explained by the significant decomposition of organic material. In other ecosystems, a high connectance index expresses detritus' important role in the trophic chain. That is why detritus is an alternative food in Lake Ayamé. It was shown by Moore et al. (2004) that plant decomposition allows mineralisation and releases nutritive salts and detritus with microbe fauna. This improves the detritus' nutritive value. Detritus is primary producers' additional food and also supports fish production.

The trophic level of the fishery is 2.94 as it targets mostly Sarotherodon melanotheron (which is at TL 2.95). This results in a situation of "immaturity" sensu Pauly et al. (1998) because this fishery exploits high trophic levels. This trophic level of the fishery is high when compared with other values obtained by Villanueva et al. (2005) and Villanueva et al. (2006), respectively, in Bagré reservoir and Ebrié lagoon which are, however, considered as immature ecosystems. Fish productivity is linked to primary production by many intermediate trophic links. The gross efficiency of the fishery is low as compared with what was observed for Lake George (Moreau et al., 1993), Lake Ihema (Mavuti et al., 1996) and Lake Victoria (Villanueva and Moreau, 2001) or other tropical inland water bodies (Christensen and Pauly, 1993). The primary production required (PPR) in order to support the fishery is high as compared with an average value suggested by Pauly and Christensen (1995) for tropical lakes and rivers (23.6\%). This may be due to the high utilisation of food resources as expressed by the high EE of most groups. 
The higher connectance index (0.396) than the theoretical value $(0.317)$ computed using the regression model of Christensen and Pauly (1993) for Lake Ayamé can be regarded as the result of the diversity of the diets of some groups and it expresses a certain level of maturity sensu (Odum, 1971). This concords with an intermediate system omnivory index value which shows specialised and generalised groups existing in the lake in terms of diet. Guild diversification contributes to ecosystem stability. Functional groups which exhibit a certain degree of diet generalisation have trophic flexibility. This flexibility confers upon them larger possibilities of adaptation (Paugy, 1994). Moreover, the fish fauna of Lake Ayamé has several species which seem adapted to pressures such as environment changes and fisheries. This is the case of Sarotherodon melanotheron, which is probably adapted to environment changes because it integrates zooplankton in its diet. Lauzanne (1988) indicates that Sarotherodon melanotheron is filter microphagous. Moreover, Lowe-McConnel (1993) shows that in man-made lakes Tilapiine fish are most adapted. This biological plasticity enables them to survive and in most cases, to dominate in considerable abundance and productivity in most tropical waters (Lévêque, 2002). According to Polis and Strong (1996), resource utilisation and ecological interactions are highly dependent on habitat heterogeneity and may explain deviation in trophic guilds and behaviours of similar taxonomic groups in different ecosystems. This adaptation has reduced competition with Oreochromis niloticus. In other words, Oreochromis niloticus disappearance can be due to fish pressure. Similar low competition between endemic and alien tilapias is exhibited in Lake Kivu (Villanueva et al., 2007) and in Lake Victoria (Twongo, 1995). Competition is also not strong between Chrysichtys spp. and Heterotis niloticus. Lauzanne (1988) noted that both consume molluscs.

\section{CONCLUSION}

The use of Ecopath provided a conventional representation of ecosystems consisting of compartments connected by trophic links or flows which provides simplified quantitative descriptive organisation of aquatic communities. It has been a useful tool in describing and understanding the trophic structure in Lake Ayamé.

The highest trophic level is 3.82 and all trophic levels are represented in this ecosystem: primary producers, low trophic level consumers, intermediate trophic levels and top predators.

The Lake Ayamé ecosystem can be qualified as stable. This relative stability is based on trophic resource abundance, notably primary producers and detritus. However, these resources are not fully utilised. This situation involves little marked competition between various species considered as important in the lake ecosystem. Lake functioning is based on trophic levels 2 and 3 . So organisms of these levels constitute key species for the lake.

The mean trophic level of catch (2.94) indicates that fisheries are targeting mainly the fish groups of high trophic levels. As a consequence, the lake resources have not yet crossed the critical threshold of overexploitation.

Differences in biomasses and productions for some groups have been pointed out, mostly for food sources, and some of them appear to be underexploited. Therefore, the implementation of an optimal use of all the food sources in inland waters appears to be a way of increasing the productivity of the fisheries.

\section{ACKNOWLEDGEMENTS}

Most of the data utilised here come from the database of the Ivorian and Belgian project VLIR financed by the General Administration for Cooperation and Development (AGCD) of the Belgium Royal Government. The authors wish to thank the stakeholders of this project for useful information and comments. 


\section{REFERENCES}

Allen K.R., 1971. Relation between production and biomass. J. Fish. Res. Board Can., 28, 1573-1581.

Andersen K.P. and Ursin E., 1977. A multispecies analysis of the efforts of variations of effort upon stock composition of eleven North Sea fish species, ICES Symposium of the Changes in the North Sea Fish stocks and Their Causes, ICES Report, 112, 286-291.

Blaber S.J.M., 2000. Tropical estuarine fishes: ecology, exploitation and conservation. Fish and aquatic resources series 7, Oxford: Blackwell, London, 372 p.

Castillo G., Li H.W. and Rossignol P.A., 2000. Absence of overall feedback in a benthic estuarine community: A system potentially buffered from impacts of biological invasions. Estuaries 23, 275-291.

Christensen V., 1995. Ecosystem maturity: towards quantification. Ecol. Modell., 77, 3-32.

Christensen V., 1998. Fishery induced changes in a marine ecosystem, insight from models of the gulf of Thailand. J. Fish Biol., 53A,128-142.

Christensen V. and Pauly D., 1992. ECOPATH II: a software for balancing steady state ecosystem models and calculating network characteristics. Ecol. Modell., 61, 169-185.

Christensen V. and Pauly D., 1993. Trophic Models of Aquatic Ecosystems, ICLARM Conference Proceedings, ICLARM Manila, Philippines.

Christensen V. and Pauly D., 1996. Ecological modelling for all. Naga the ICLARM Quarterly, 19, 25-26.

Christensen V. and Walters C., 2004. Ecopath with Ecosim: methods, capabilities and limitations. Ecol. Modell., 172, 109-139.

Christensen V., Walters C.J. and Pauly D., 2000. Ecopath with Ecosim: A user's guide, October 2000, Fisheries Centre, University of British Columbia, Vancouver, Canada et ICLARM, Penang Malaysia [available on website URL: http://www.ecopath.org/].

Christensen V., Walters C. and Pauly D., 2005. Ecopath with Ecosim: a User's Guide. Fisheries Centre Report, 130 p., Fisheries Center, University of British Columbia, Vancouver, Canada and www.ecopath.org

Daget J. and Iltis A., 1965. Poissons de Côte d'Ivoire (Eaux douces et saumâtres). Mémoire de l'Institut Fondamental d'Afrique Noire, 74, $385 \mathrm{p}$.

Dietoa Y.M., Gourène G. and Ouattara A., 2007. Habitudes alimentaires de Brycinus longipinnis dans le complexe fluvio-lacustre de la Bia, Côte d'Ivoire. Belg. J. Zool., 137, 3-9.

Diomande D. and Gourène G., 2005. Premières données sur la macrofaune benthique de I'hydrosystème fluvio-lacustre de la Bia (Côte d'Ivoire). Sciences et Nature, 2, 167-176.

Diomande D., Gourène G. and Tito de Morais L., 2001. Stratégies alimentaires de Synodontis bastiani (Siluriformes: Mochokidae) dans le complexe fluvio-lacustre de la Bia, Côte d'Ivoire. Cybium, 25, 7-21.

Dufour P., 1994. Les microphytes. In: Durand J.R., Dufour P., Guiral D., Zabi S.G.F. (eds.), Environnement et ressources aquatiques de Côte d'Ivoire, Tome II - Les milieux lagunaires, ORSTOM, Paris, 109-136.

Dyer L.A. and Letourneau D., 2003. Top-down and bottom-up diversity cascades in detrital vs. living food webs. Ecol. Lett., 6, 60-68.

Froese R. and Binohlan C., 2000. Empirical relationships to estimate asymptotic length, length at first maturity and yield at maximum yield per recruitment in fishes, with a simple method to evaluate length frequency data. J. Fish Biol., 56, 758-773.

Froese R. and Pauly D., 2007. FishBase [available on website URL: http://www.fishbase.org/].

Gamito S. and Erzini K., 2005. Trophic food web and ecosystem attributes of a water reservoir of the Ria Formosa (south Portugal). Ecol. Modell., 181, 509-520.

Gayanilo F.C. Jr., Sparre P. and Pauly D. (eds.), 2002. The FAO-ICLARM Stock Assessment Tools II (FiSAT II Ver. 1.0), FAO [available on website URL: http://www.fao.org/fi/statist/fisoft/fisat/].

Gourène G.G., Teugels G., Hugueny B. and Thys Van Den Audernaerde D.F.E., 1999. Évaluation de la diversité ichtyologique d'un bassin ouest africain après la construction d'un barrage. Cybium, 23, 147-160.

Haputhantri S.S.K., Villanueva M.C. and Moreau J., 2008. Trophic interactions in the coastal ecosystem of Sri Lanka: an ECOPATH preliminary approach. Estuarine Coastal Shelf Sci., 76, 304-318.

Ivan E., Silva L. and Schiemer F., 2008. Regulation of primary production in Sri Lankan reservoirs, In: Schiemer F., Simon D., Amarasinghe U.S. and Moreau J. (eds), Aquatic ecosystems and development comparative Asian perspectives. Hydrobiology (in press). 
Kone T. and Teugels G.G., 2003. Food habits of brackish water tilapia Sarotherodon melanotherodon in riverine and lacustrine environment of a West African coastal basin. Hydrobiologia, 490, 75-85.

Kouamelan E.P., Teugels G.G., Gourène G., Ollevier F. and Thys Van Den Audernaerde D.F.E., 1999. The effect of man-made lake on the diet of the African electric fish Mormyrus rume Valenciennes, 1846 (Osteoglossiformes; Mormyridae). Hydrobiologia, 380, 141-151.

Kouamelan E.P., Teugels G.G., Gourène G., Thys Van Den Audenaerde D.F.E. and Ollevier F., 2000. Habitudes alimentaires de Mormyrops anguilloides (Mormyridae) en milieux lacustre et fluvial d'un bassin Ouest-africain. Cybium, 24, 67-79.

Laevastu T. and Larkin H.A., 1981. Marine fisheries ecosystem. Its quantitative evaluation and management, Fishing News Books, Farnham.

Lauzanne L., 1983. Trophic relations of fishes in Lake Chad. In: Carmouze J.P, Durand J.R., Lévêque C. (eds.), Lake Chad: Ecology and productivity of a shallow tropical ecosystem, Junk Publ., The Hague, 489-518.

Lauzanne L., 1988. Les habitudes alimentaires des poissons d'eau douce africains. In: Lévêque C., Bruton M., Ssentongo G. (eds.), Biologie et écologie des poissons d'eau douce africains, ORSTOM, Paris, 221-242.

Lévêque C., 2002. Out of Africa, the success story of Tilapias. Environ. Biol. Fishes, 64, 461-464.

Lévêque C., Durand J.R. and Ecoutin J.M., 1977. Relation entre le rapport P/B et la longévité chez les organismes. Cahiers de l'ORSTOM, série Hydrobiologie, 11, 17-32.

Lindeman R.L., 1942. The trophic dynamic aspect of ecology. Ecology, 23, 399-418

Loreau M., Naeem S., Inchausti P., Bengtsson J., Grime J.P., Hector A., Hooper D.U., Huston M.A., Raffaelli D., Schmid B., Tilman D. and Wardle D.A., 2001. Biodiversity and ecosystem functioning: Current knowledge and future challenges. Science 294, 804-808.

Lowe-McConnell R.H., 1987. Ecological studies in tropical fish communities, Cambridge University Press, Cambridge, UK, $382 \mathrm{p}$.

Lowe-McConnell R.H., 1993. Fish Faunas of the African Great Lakes: Origins, Diversity, and Vulnerability. Conservation Biology, 7, 634-643.

Mavuti K., Moreau J., Munyandorero J. and Plisnier D., 1996. Analysis of trophic relationships in two shallow equatorial lakes: Lake Naivasha (Kenya) and Lake Ihema (Rwanda) using a multispecifies trophic model. Hydrobiologia, 321, 89-100.

Merona B., 1983. Modèle d'estimation rapide de la croissance des poissons d'eau douce d'Afrique. Revue d'Hydrobiologie Tropicale, 16, 103-116.

Moore J.C., Berlow E.L., Coleman D.C., De Ruiter P.C., Dong Q., Hastings A., Collins Johnson N., McCann K.S., Melville K., Morin P.J., Nadelhoffer K., Rosemond A.D., Post D.M., Sabo J.L., Scow K., Vanni M. and Wall D., 2004. Detritus, trophic dynamics and biodiversity. Ecol. Lett., 7, 584-600.

Moreau J. and Villanueva M.C., 2002. Exploratory analysis of possible management strategies in Lake Victoria (Kenyan sector) using the recent Ecosim software. In: Pitcher T., Cochrane K. (eds.), On the use of ecosystem models to investigate multi-species management strategies for capture fisheries. Fisheries Centre Research Reports, 10, 150-154 [available on website URL: www.fisheries.ubc.ca].

Moreau J., Arrignon J. and Jubb R., 1988. Les introductions d'espèces étrangères dans les eaux continentales africaines, Intérêt et limites. In: Lévêque C., Bruton M.N., Ssentongo G.W., (Eds.), Biologie et écologie des poissons d'eau douce africains, ORSTOM, Paris, 221-242.

Moreau J., Christensen V. and Pauly D., 1993. A trophic ecosystem model of Lake George, Uganda. In: Christensen V. and Pauly D. (eds.), Trophic Models of Aquatic Ecosystems, ICLARM Conference, 124-129.

Moreau J., Mavuti K. and Daufresne T., 2001. A synoptic Ecopath model of biomass flows during two different static ecological situations in lac Nakuru (Kenya). Hydrobiologia, 458, 63-74.

Naeem S. and Li S., 1997. Biodiversity enhances ecosystem reliability. Nature 390, 507-509.

Odum E.P., 1969. The strategy of ecosystem development. Science, 104, 262-270.

Odum E.P., 1971. Fundamentals of ecology, W.B. Saunders Co, Philadelphia, 574 p.

Odum W.E. and Heald E.J., 1975. The detritus-based food web of an estuarine mangrove community. In: Cronin L.E. (ed.), Estuarine Research Academic, Press, Inc., London.

Ouattara A., Podoor N. and Gourène G., 2003. Études préliminaires de la distribution spatio-temporelle du phytoplancton d'un système fluvio-lacustre (Bia, Côte d'Ivoire). Hydroécologie appliquée, 73, $1-20$.

Ouattara A., Podoor N. and Gourène G., 2007. Activité photosynthétique du phytoplancton dans le barrage hydroélectrique d'Ayamé I (Côte d'Ivoire). Agronomie Africaine, 19, 63-70. 
Palomares M.L., 1991. La consommation de nourriture chez les poissons, étude comparative, mise au point d'un modèle prédictif et application à l'étude des réseaux trophiques. Thèse de doctorat, Institut National Polytechnique de Toulouse, France.

Palomares M.L.D. and Pauly D., 1998. Predicting food consumption of fish populations as functions of mortality, food type, morphometrics, temperature and salinity. Mar. Freshw. Res., 49, 447-453.

Paugy D., 1994. Écologie des poissons tropicaux d'un cours d'eau temporaire (Baoulé, haut bassin du Sénégal au Mali): adaptation au milieu et plasticité du régime alimentaire. Revue d'Hydrobiologie Tropicale, 27, 157-172.

Pauly D., 1980. On the interrelationships between natural mortality, growth parameters and mean environmental temperature. In: 175 fish stocks, Journal du Conseil International pour l'Exploration de la Mer, 39, 175-192.

Pauly D., 1983. Some simple methods for the assessment of tropical fish stocks. FAO Fisheries Technical Paper, 234.

Pauly D. and Christensen V., 1995. Primary production required to sustain global fisheries. Nature, 374 , 255-257.

Pauly D., Palomares M.L.D. and Moreau J., 1988. Detritus and energy consumption and conversion efficiency of Sarotherodon melanotheron (Cichlidae) in a West African lagoon. J. Appl. Ichthyol., 4, 190-193.

Pauly D., Palomares M.L.D. and Froese R., 1993. Some prose on a database of indigenous knowledge on fish. IK and Development Monitor, 1, 26-27.

Pauly D., Christensen V., Dalsgaard J., Froese R. and Torres F.C. Jr., 1998. Fishing down marine food webs. Science, 279, 860-863.

Perez-España H. and Arreguin-Sanchez F., 1999. A measure of ecosystem maturity. Ecol. Modell., 119, 79-85.

Perez-España H. and Arreguin-Sanchez F., 2001. An inverse relationship between stability and maturity in models of aquatic ecosystems, Ecol. Modell., 145, 189-196.

Platts T. and Ulanowicz R.E. (eds.) 1985. Ecosystem theory for biological oceanography. Can. B. Fish. Aquat. Sci., 213, 260 p.

Polis G.A. and Strong D.R., 1996. Food web complexity and community dynamics. Am. Nat., 147, 813-846.

Polovina J.J., 1984. Model of a coral reef ecosystem, The ECOPATH model and its application to French Frigate Shoals. Coral Reefs, 3, 1-11.

Polovina J.J. and Ow M.D., 1985. An approach to estimating an ecosystem box model. Fisheries Bulletin, 83, 457-460.

Reizer C., 1967. Aménagement piscicole du lac artificiel d'Ayamé. Publication n 30 du C.T.F.T., 108 p.

Ricker W.E., 1969. Food from the sea. In: Treeman W.H. (ed.), Resources and Man, A Study and Recommendations by the Committee on Resources and Man, San Francisco, 87-108.

Thapanand T., Moreau J., Jutagate T., Wongrat P., Lekcholayut T., Meksumpun C., Janekitkarn S., Rodloi A., Dulyapruk V. and Wongrat L., 2007. Towards possible fishery management strategies in a newly impounded man-made lake in Thailand. Ecol. Modell., 204, 143-155.

Twongo T., 1995. Impact of fish species introductions on the tilapias of Lake Victoria and Kyoga. In: Pitcher T.J., Hart P.J.B. (eds.), The impact of species changes in African Lakes, Fish and Fisheries Series 18, Chapman and Hall, London, 45-57.

Ulanowicz R.E., 1986. Growth and development: ecosystem phenomenology, Springer Verlag, New York, 203 p.

Ulanowicz R.E., 1995. Ecosystem trophic foundations: Lindeman exonerate. In: Patten B.C., Jorgensen S.E. (eds.), Complex Ecology: The Part-whole Relation in Ecosystems, Prentice-Hall, Englewood Cliff, 549-560.

Vanga A.F., Gourène G. and Ouattara M., 2002. Impact de la pêche sur la disponibilité en poissons dans les régions des lacs d'Ayamé et de Buyo (Côte d'Ivoire). Archives Scientifiques, CRO/ORSTOM, Vol. XVII, 1-12.

Villanueva M.C., Isumbisho M., Kaningini M., Moreau J. and Micha J.C., 2008. Modelling trophic interactions in Lake Kivu, what role do exotics play? Ecol. Modell., 212, 422-438.

Villanueva M.C., Laleye P., Albaret J.J., Lae R., Tito de Morais L. and Moreau J., 2006. Comparative analysis of trophic structures and interactions of two tropical lagoons. Ecosystem Modelling, 197, 461-477.

Villanueva M.C, Ouedraogo M. and Moreau J., 2005. Relationship in the recently impounded Bagré reservoir in Burkina Faso. Ecol. Modell., 191, 243-259. 
Villanueva M.C. and Moreau J., 2001. Recent trends of evolution in Lake Victoria fisheries as assessed by Ecopath 4 (with Ecosim) software, In: Cowx I.G. (ed.), Lake and Reservoirs Fisheries Management, UK, The University of Hull, 96-110.

von Bertalanffy L., 1938. A quantitative theory of organic growth. Human Biology, 10, 181-213.

Walters C., Christensen V. and Pauly D., 1997. Structuring dynamic models of exploited ecosystems from trophic mass balanced assessments. Rev. Fish Biol. Fisher., 7, 139-172.

Walters C., Pauly D. and Christensen V., 1999. Ecospace, prediction of meso-scale spatial patterns in trophic relationships of exploited ecosystems, with emphasis on the impacts of marine protected areas. Ecosystems, 2, 539-554.

Walters C., Pauly D., Christensen V. and Kitchell J.F., 2000. Representing density dependent consequences of life history in aquatic ecosystems, Ecosim II. Ecosystems, 3, 70-83.

Yodzis P. and Winemiller K.O., 1999. In search of operational trophospecies in a tropical aquatic food web. Oïkos, 87, 327-340. 